\title{
Crystallization Behavior of High Purity Amorphous Silicon Nitride Fiber
}

\author{
Hideki MATSUO, Osamu FUNAYAMA, Tomohiro KATO, Hiroshi KAYA and Takeshi ISODA \\ Corporate Research \& Development Laboratory, Tonen Corporation, 1-3-1, Nishi-Tsurugaoka, Ohi-machi, Imuma-gun, Saitama 356
}

\author{
高純度非晶質窒化ケイ素繊維の結晶化挙動 \\ 松尾英樹・舟山 徹・加藤智浩・茅 博司・礒田武志 \\ 東然(株)総合研究所, 356 埼玉県入間郡大井町西鶴尔岡 1-3-1
}

[Received October 21, 1993; Accepted February 16, 1994]

\begin{abstract}
The crystallization of high purity polymer-derived amorphous $\mathrm{Si}_{3} \mathrm{~N}_{4}$ fiber was investigated. The amorphous $\mathrm{Si}_{3} \mathrm{~N}_{4}$ fiber was heat-treated $(1400,1425,1450$, 1475 and $1500^{\circ} \mathrm{C}$, for $1-100 \mathrm{~h}$ in $\mathrm{N}_{2}$ ), and the crystallinity was estimated from X-ray diffraction patterns. Hexagonal crystalline particles growing on the surface of the fiber were observed by SEM. The crystallization seems to proceed by the vapor phase growth mechanism, in which SiO vapor takes part as silicon carrier between amorphous fiber and crystalline particles. Whille BN powder was used as a powder bed, the crystallization and grain growth were retarded and crystalline particles were grown inside the fiber. In this case the crystallization seems to proceed by the solid phase growth mechanism. The activation energies were calculated for heat treatment with and without $\mathbb{B N}$ powder and found to be about 1273 and $602 \mathrm{~kJ} / \mathrm{mol}$, respectively. Durability of $\mathrm{Si}_{3} \mathrm{~N}_{4}$ fiber at 1300 and $1400^{\circ} \mathrm{C}$ was estimated.
\end{abstract}

Key-words : Amorphous, Silicon nitride fiber, Polysilazane, Crystallization, Activation energy

\section{Introduction}

The properties of silicon nitride, for example, resistance to thermal shock, corrosion, creep and oxidation, continue to generate interest in its application as high-temperature structural material, and an insulating diffusion mask in electric devices. Dense sintered silicon nitride has excellent high-temperature strength, high-electrical resistivity, low coefficient of thermal expansion, and low density relative to other high-temperature ceramics and superalloys, but these sintered silicon nitride contains impurity, which takes part as sintering agent, such as $\mathrm{Y}_{2} \mathrm{O}_{3}{ }^{1)}$ or $\mathrm{Al}_{2} \mathrm{O}_{3}$, ${ }^{2}$ etc. Therefore the sintered silicon nitride has not been representing the intrinsic properties of silicon nitride.

Recently considerable attention has been directed to the use of inorganic polymers as precursors to high-temperature and high-performance ceramics such as $\mathrm{Si}_{3} \mathrm{~N}_{4}$. Some of the potential advantages in the preparation of ceramic materials from these precursors include as follows:6) (1) improved compositional homogeneity in the product because of mixing of elemental components in the molecular and atomic levels, (2) high-purity ceramic products with uniform, small-grained microstructures, (3) the ability to produce high-surface area powders of controlled morphology and (4) the preparation of refractory ceramics at relatively low temperatures. Furthermore, the solubility and fluidity of inorganic polymers afford potential processing routes to binders, sintering aids, thin films and fiber. Thin films and fiber are often difficult or impossible to produce by the more traditional ceramic processing techniques.

Perhydropolysilazane (PHPS), produced by Tonen Corporation, ${ }^{3)}$ is an inorganic polymer as precursor for $\mathrm{Si}_{3} \mathrm{~N}_{4}$ and $\mathrm{SiO}_{2}$ and contains only silicon, nitrogen and hydrogen. High-purity $\mathrm{Si}_{3} \mathrm{~N}_{4}$ without sintering aids can be obtained by pyrolyzing PHPS.

The studies of crystallization of amorphous silicon nitride have been reported by some working groups. ${ }^{4)-6)}$ Yamada et al.4) synthesized amorphous silicon nitride with thermal decomposition of $\mathrm{Si}(\mathrm{NH})_{2}$. Hojo et al. ${ }^{5}$ synthesized amorphous silicon nitride with thermal decomposition of vapor reaction method. Schmidt et al. ${ }^{6}$ reported the preparation and crystallization of crystalline silicon nitride by pyrolysis of organometallic precursor in $\mathrm{NH}_{3}$.

In this paper, we present crystallization behavior of high purity amorphous silicon nitride fiber obtained from PHPS. We also discuss crystallization mechanism and activation energy.

\subsection{Preparation}

\section{Experimental}

PHPS that is a precursor of silicon nitride was synthesized by reacting dichrolosilane with $\mathrm{NH}_{3}$ in pyridine at $0^{\circ} \mathrm{C}$. PHPS's simplified structure was given by

$$
\left(-\mathrm{SiH}_{2}-\mathrm{NH}-\right)_{n}
$$

This polysilazane is a transparent liquid with low viscosity, composed of silicon, nitrogen and hydrogen. It was heated in pyridine with $\mathrm{NH}_{3}$ at $80^{\circ} \mathrm{C}$ to obtain solid polymer that is soluble in pyridine, xylene, etc. PHPS fiber was continuously prepared by dry spinning. The PHPS fiber was pyrolyzed at $600^{\circ} \mathrm{C}$ for $1 \mathrm{~h}$ in $\mathrm{NH}_{3}$ and subsequently annealed at $1300^{\circ} \mathrm{C}$ for $1 \mathrm{~h}$ in $\mathrm{N}_{2}$. We obtained $\mathrm{Si}_{3} \mathrm{~N}_{4}$ fiber, which shows no peak in the $\mathrm{X}$-ray diffraction measurement and no lattice image in the high-resolutional transmission 


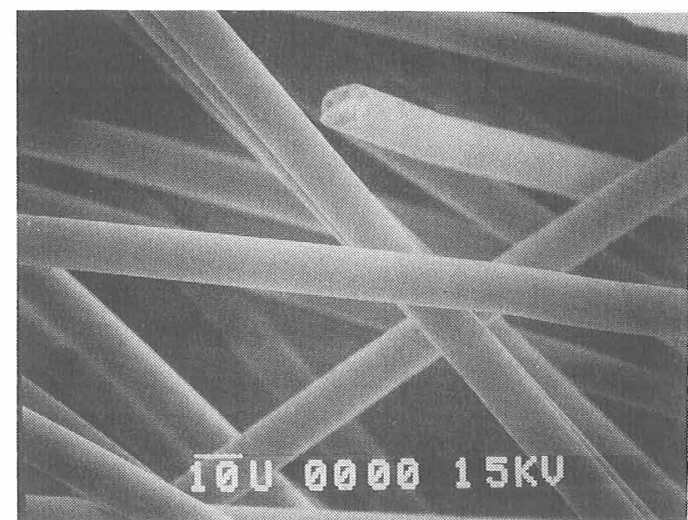

Fig. 1. SEM photograph of fresh $\mathrm{Si}_{3} \mathrm{~N}_{4}$ fiber.

Table 1. An Elemental Analysis of the Amorphous PHPS-Derived $\mathrm{Si}_{3} \mathrm{~N}_{4}$ Fiber

\begin{tabular}{cccccc}
\hline \multirow{2}{*}{ sample } & \multicolumn{4}{c}{ Composition (wt\%) } & \multirow{2}{*}{ Si/N } \\
\cline { 2 - 5 } & $\mathrm{Si}$ & $\mathrm{N}$ & $\mathrm{O}$ & $\mathrm{C}$ & \\
\hline Amorphous Si3N4 fiber* & 58.3 & 37.4 & 3.58 & 0.7 & 0.78 \\
\hline \hline
\end{tabular}

*The fiber was obtained by $\mathrm{N} 2$-annealing at $1300^{\circ} \mathrm{C}$ for $1 \mathrm{~h}$ after pyrolyzing at $600^{\circ} \mathrm{C}$ in $\mathrm{NH}_{3}$ for $1 \mathrm{~h}$.

electron micrograph (TEM). These results indicate that the structure of $\mathrm{Si}_{3} \mathrm{~N}_{4}$ fiber is amorphous. Figure 1 shows scanning electron microscopy (SEM) of the $\mathrm{Si}_{3} \mathrm{~N}_{4}$ fiber.

Table 1 shows elemental analysis result of this amorphous $\mathrm{Si}_{3} \mathrm{~N}_{4}$ fiber. The $\mathrm{Si} / \mathrm{N}$ atomic ratio is 0.78 , which is close to stoichiometric $\mathrm{Si}_{3} \mathrm{~N}_{4}$. We assume that surplus $\mathrm{Si}$ is caused by $\mathrm{SiO}_{x}$ or dangling bond.

\subsection{Heat treatment}

Fiber was placed (1) on a carbon boat, or (2) inbedded in BN powder. The fiber was heated in a programmable electric furnace at 1400, 1425, 1450, 1475 and $1500^{\circ} \mathrm{C}$ for $1-100 \mathrm{~h}$ in $\mathrm{N}_{2}$ flow. Heating rate was $10^{\circ} \mathrm{C}$ per min.

\subsection{Characterization}

$\mathrm{X}$-ray diffraction (XRD) measurements were performed on heat-treated fiber with $\mathrm{Cu} \mathrm{K} \alpha$ radiation using an automated powder diffractometer with a monochromator. ${ }^{*}$ Yamada et al.7) reported amorphous fraction estimated from the amount of evolved $\mathrm{NH}_{3}$ in the hydrolysis of partially crystallized $\mathrm{Si}_{3} \mathrm{~N}_{4}$ was in good agreement with that determined by XRD measurement. We determined degree of crystallinity from integrated intensity of (101), (201), (102) and (210) peaks of $\alpha-\mathrm{Si}_{3} \mathrm{~N}_{4}$.

Transmission electron microscopy (TEM), selected area electron diffraction were used for crystal phase detection, and the morphology of the fiber was observed by scanning electron microscopy (SEM).

\section{Results and discussion}

\subsection{Heat treatment without BN powder} Prochazka and Greskovich ${ }^{8)}$ reported the crystalli-

\footnotetext{
* Model RINT, Rigaku Denki Co., Ltd.
}

zation of amorphous $\mathrm{Si}_{3} \mathrm{~N}_{4}$ powder synthesized from $\mathrm{SiH}_{4}-\mathrm{NH}_{3}$ began over $1480^{\circ} \mathrm{C}$ in $\mathrm{N}_{2}$. Futaki et al.9) also reported the crystallization temperature of amorphous $\mathrm{Si}_{3} \mathrm{~N}_{4}$ powder synthesized from $\mathrm{SiCl}_{4}-\mathrm{H}_{2}-\mathrm{NH}_{3}$ in a hybrid plasma was as high as $1500^{\circ} \mathrm{C}$ in $\mathrm{N}_{2}$, and Hojo et al. ${ }^{5}$ ) also reported the crystallization temperature of amorphous $\mathrm{Si}_{3} \mathrm{~N}_{4}$ powder synthesized from $\mathrm{Si}\left(\mathrm{CH}_{3}\right)_{4}-\mathrm{NH}_{3}$ occurred between 1500 and $1550^{\circ} \mathrm{C}$ in $\mathrm{N}_{2}$. In these cases crystal phase was only $\alpha-\mathrm{Si}_{3} \mathrm{~N}_{4}$.

Figure 2(a) shows time dependence of crystallinity of amorphous $\mathrm{Si}_{3} \mathrm{~N}_{4}$ fiber that was heated at 1400 , 1450 and $1500^{\circ} \mathrm{C}$. The crystallinity of the amorphous

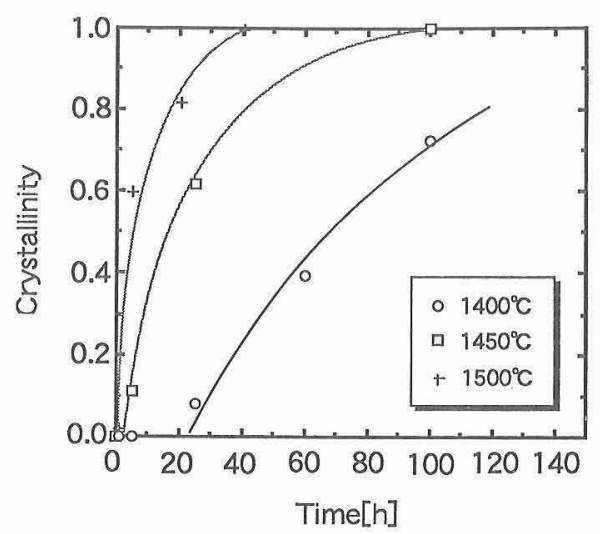

(a)

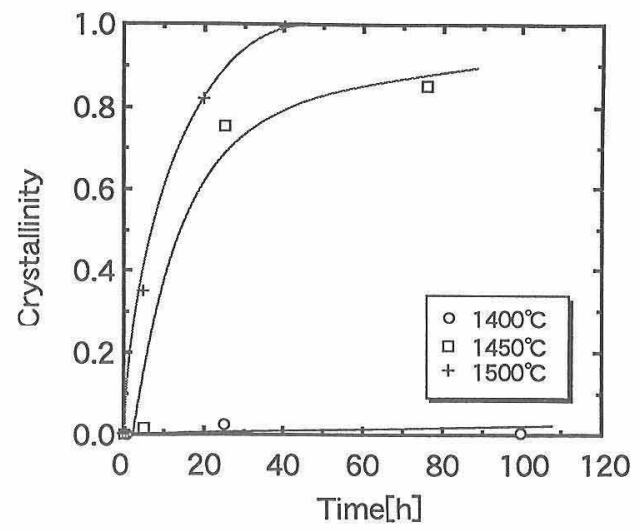

(b)

Fig. 2. (a) Time dependence of crystallinity of amorphous $\mathrm{Si}_{3} \mathrm{~N}_{4}$ fiber that was heated at 1400,1450 and $1500^{\circ} \mathrm{C}$ : heat treatment without $\mathrm{BN}$ powder, (b) Time dependence of crystallinity of amorphous $\mathrm{Si}_{3} \mathrm{~N}_{4}$ fiber that was heated at 1400,1450 and $1500^{\circ} \mathrm{C}$ : heat treatment with $\mathrm{BN}$ powder.

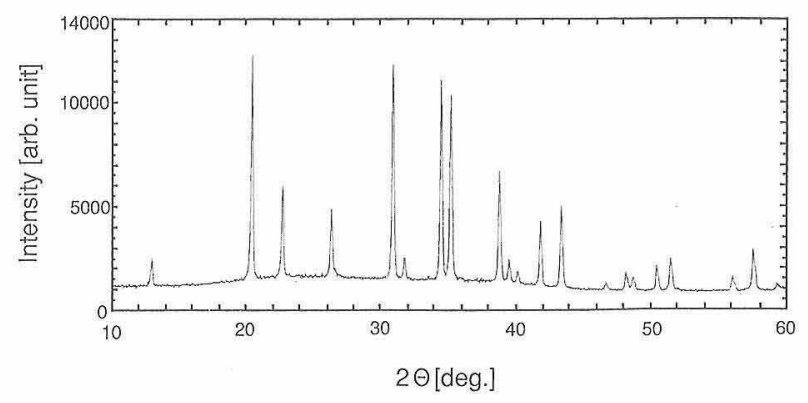

Fig. 3. X-ray diffraction pattern of heat-treated amorphous $\mathrm{Si}_{3} \mathrm{~N}_{4}$ fiber at $1500^{\circ} \mathrm{C} \times 5 \mathrm{~h}$. 


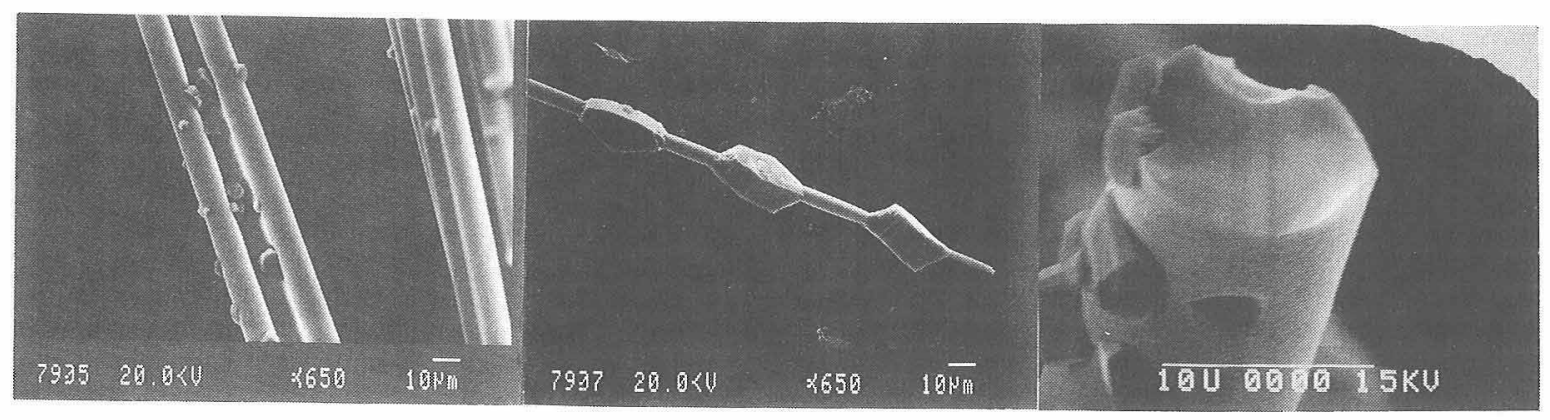

(a)

(b)

(c)

Fig. 4. $\mathrm{SEM}$ photographs of heat-treated $\mathrm{Si}_{3} \mathrm{~N}_{4}$ fiber without $\mathrm{BN}$ powder. (a) Heat treatment at $1400^{\circ} \mathrm{C} \times 25 \mathrm{~h}$, (b) Heat treatment at $1400^{\circ} \mathrm{C} \times 100 \mathrm{~h}$, (c) Fracture surface of heat-treated fiber at $1400^{\circ} \mathrm{C} \times 25 \mathrm{~h}$.

$\mathrm{Si}_{3} \mathrm{~N}_{4}$ fiber at $1400^{\circ} \mathrm{C}$ for $100 \mathrm{~h}$ is 0.7 . The crystallinity is already 0.6 for heat-treated fiber at $1500^{\circ} \mathrm{C}$ for 5h. This tendency is consistent with the Refs.5),8),9)

Figure 3 shows typical $\mathrm{X}$-ray diffraction patterns. Crystal phase is only $\alpha$ - $\mathrm{Si}_{3} \mathrm{~N}_{4}$. It is known that $\alpha \rightarrow \beta$ phase transformation proceeds via. liquid phase. ${ }^{10)}$ This suggests that liquid phase does not produce in $\mathrm{Si}_{3} \mathrm{~N}_{4}$ fiber.

From the elemental analysis of the amorphous $\mathrm{Si}_{3} \mathrm{~N}_{4}$ fiber (Table 1), a small amount of impurities such as carbon and oxygen exist in the fiber. We assume that carbon is caused by xylene which is the solution of the spinning dope. $\mathrm{SiC}$ and carbon phases are not found from various measurements. This carbon seems to exist as free carbon. Oxygen is presumably originated from the adventitious water incorporated into the fiber during manufacturing steps such as spinning and pyrolysis.

SEM and TEM photographs of the heat-treated fiber at $1400^{\circ} \mathrm{C}$ are shown in Figs. 4 (a) - (c) and Fig. 5. Whisker was not found in these fibers. The particle size seems to increase with increasing crystallinity. The size of the particles on the fiber, which have 0.7 crystallinity, did not change for further calcination. The maximum size of the particle is about 20 $\mu \mathrm{m}$. TEM photograph shows crystalline particles

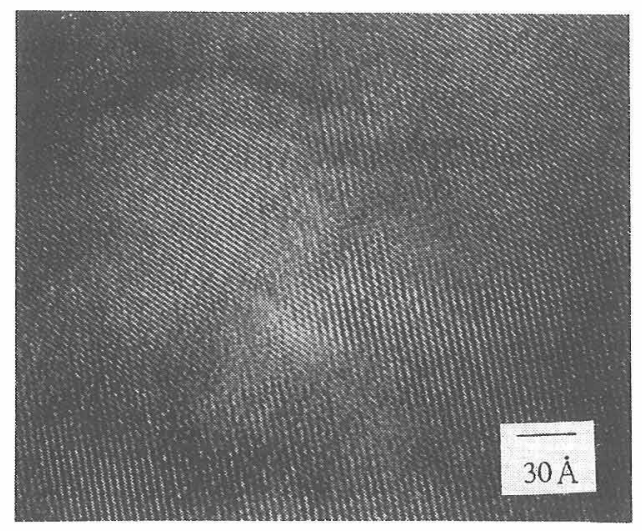

$\times 3,000,000$

Fig. 5. TEM photograph of heat treatment at $1400^{\circ} \mathrm{C} \times 100 \mathrm{~h}$ without $\mathrm{BN}$ powder. are all $\alpha-\mathrm{Si}_{3} \mathrm{~N}_{4}$. By Fig. 4(c), the crystalline particles seem to grow on the surface of the fiber, and they are not found inside of the fiber. This suggests that crystallization proceeds by vapor phase growth mechanism.

The kinetic data, shown in Fig. 2, could be represented by first order kinetic equation defined as follows. ${ }^{4)}$

$$
\frac{\mathrm{d} \alpha}{\mathrm{d} t}=k(1-\alpha)
$$

were $k$ is a reaction rate constant, $\alpha$ is the weight fraction of crystalline $\mathrm{Si}_{3} \mathrm{~N}_{4}$ in the samples and $t$ is the isothermal ageing time. The temperature dependence of the rate constant $k$ is given by the Arrhenius equation :

$$
k=A e^{-E / R T}
$$

where $A$ is a frequency factor, $E$ the activation energy for crystallization, $R$ the gas constant and $T$ the absolute temperature.

Figure 6 (a) shows Arrhenius plot of the rate constant against temperature in the crystallization of amorphous $\mathrm{Si}_{3} \mathrm{~N}_{4}$ fiber. This one was obtained from Fig. 2(a). From this, an activation energy of $602 \mathrm{~kJ} /$ mol was calculated. This value is smaller than that of $890 \mathrm{~kJ} / \mathrm{mol}$ reported by Yamada et al.,4) but larger than that of $306 \mathrm{~kJ} / \mathrm{mol}$ reported by Riedel. ${ }^{11)}$ The difference of the value is due to the purity of samples, the sample of Yamada et al. is high purity but the sample of Riedel contains 5.3 wt\% oxygen and $0.8 \mathrm{wt} \%$ chlorine.

Rate constant of crystallinities of $\mathrm{Si}_{3} \mathrm{~N}_{4}$ fiber was considerably small, compared with that of other powder samples. This experimental result may be understood by taking account of the specific surface area. The value of the surface area of our smooth columnar fiber is calculated $1.7 \mathrm{~m}^{2} / \mathrm{g}$ from diameter of $10.0 \mu \mathrm{m}$ and density of $2.4 \mathrm{~g} / \mathrm{cm}^{3}$. The specific surface areas of reported $\mathrm{Si}_{3} \mathrm{~N}_{4}$ powder samples, other polymeric precursors using plasma $\left(60-70 \mathrm{~m}^{2} / \mathrm{g}\right)$ for pyrolysis ${ }^{9)}$ are larger than our fiber.

According to our experimental results, crystallization of amorphous $\mathrm{Si}_{3} \mathrm{~N}_{4}$ fiber without $\mathrm{BN}$ powder proceeds by vapor phase growth mechanism. It has been discussed that thin $\mathrm{SiO}_{2}$ layer exists on surface 


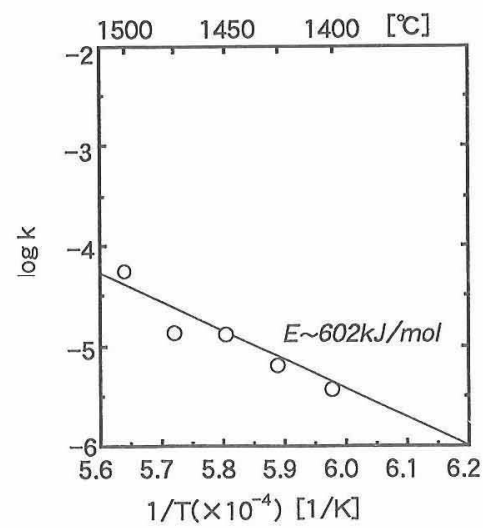

(a)

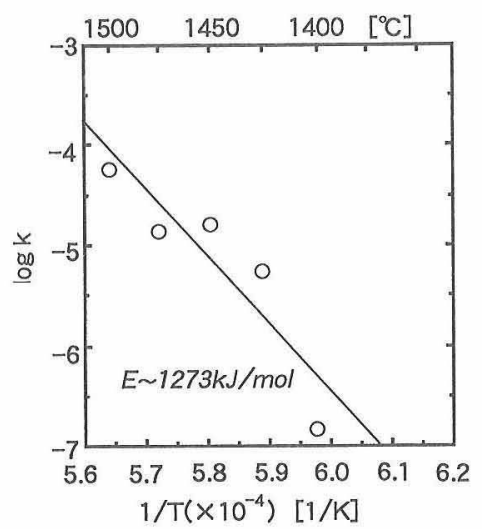

(b)

Fig. 6. (a) Arrhenius plot of the rate constant in the crystallization of amorphous $\mathrm{Si}_{3} \mathrm{~N}_{4}$ fiber: heat treatment without $\mathrm{BN}$ powder, (b) Arrhenius plot of the rate constant in the crystallization of amorphous $\mathrm{Si}_{3} \mathrm{~N}_{4}$ fiber: heat treatment with $\mathrm{BN}$ powder.

of $\mathrm{Si}_{3} \mathrm{~N}_{4}$ and that $\mathrm{SiO}$ gas occurs from $\mathrm{SiO}_{2}$ in low oxygen partial pressures. Reaction of vapor $\mathrm{SiO}$ with $\mathrm{N}_{2}{ }^{5)}$ may nucleate crystalline $\mathrm{Si}_{3} \mathrm{~N}_{4}$.

\subsection{Heat treatment with BN powder}

Time dependence of crystallinity of amorphous $\mathrm{Si}_{3} \mathrm{~N}_{4}$ fiber, which was heat-treated in $\mathrm{BN}$ powder at 1400,1450 and $1500^{\circ} \mathrm{C}$ for $1 \mathrm{~h}$, is shown in Fig. 2(b). Comparing to heat-treating without $\mathrm{BN}$ powder, it is clear that crystallization is particularly retarded at 1400 and $1450^{\circ} \mathrm{C}$. The crystallinity for heat treatment at $1400^{\circ} \mathrm{C}$ for $100 \mathrm{~h}$ was about 0.01 . But the crystallinity became 0.35 when the fiber was heat-treated in $\mathrm{BN}$ powder at $1500^{\circ} \mathrm{C}$ for $5 \mathrm{~h}$. Only $\alpha-\mathrm{Si}_{3} \mathrm{~N}_{4}$ was observed by XRD measurement.

Figure 7 shows SEM photographs of heat-treated fiber at $1400^{\circ} \mathrm{C}$ in $\mathrm{BN}$ powder. Crystalline particles can not be observed by SEM. These experimental results indicate that BN powder suppresses the crystallization and crystal growth. Hojo et al.5) reported that $\mathrm{BN}$ powder suppressed evolution of $\mathrm{SiO}$ gas. $\mathrm{BN}$ powder suppresses crystallization of amorphous $\mathrm{Si}_{3} \mathrm{~N}_{4}$ through vapor phase.

According to these experimental results, in the case of heat treatment in $\mathrm{BN}$ powder, we assume that crystallization proceeds by solid phase growth

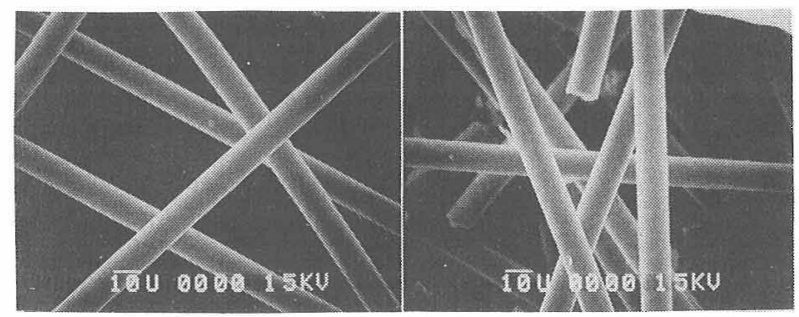

(a)

(b)

Fig. 7. SEM photographs of heat-treted $\mathrm{Si}_{3} \mathrm{~N}_{4}$ fiber with $\mathrm{BN}$ powder. (a) Heat treatment at $1400^{\circ} \mathrm{C} \times 25 \mathrm{~h}$, (b) Heat treatment at $1400^{\circ} \mathrm{C} \times 100 \mathrm{~h}$.

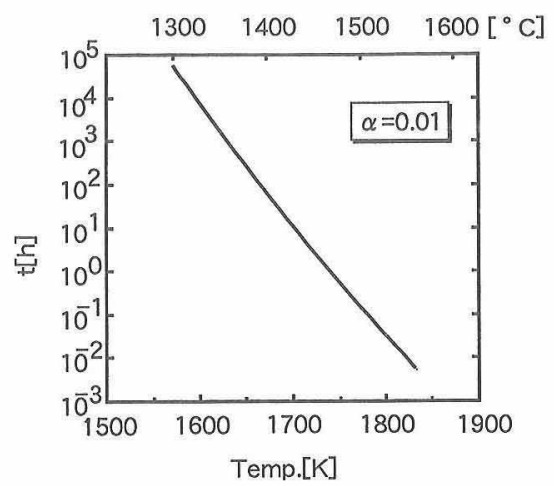

Fig. 8. Relation between heat-treated time and temperature when the crystallinity $\alpha$ is assumed 0.01 .

mechanism.

Arrhenius plot of the rate constant against temperature in the crystallization of amorphous $\mathrm{Si}_{3} \mathrm{~N}_{4}$ fiber in $\mathrm{BN}$ powder is shown in Fig. 6(b). An activation energy of $1273 \mathrm{~kJ} / \mathrm{mol}$ was considered. This value is about twice larger than the value of $602 \mathrm{~kJ} / \mathrm{mol}$ which was calculated from heat-treated fiber without $\mathrm{BN}$ powder. $1273 \mathrm{~kJ} / \mathrm{mol}$ is thought to be the intrinsic activation energy of crystallization of $\mathrm{Si}_{3} \mathrm{~N}_{4}$ fiber.

In ceramic matrix composite, ceramic fiber is surrounded with dense matrix. Crystallization of amorphous ceramic fiber via vapor phase may be inhibited. Durability of $\mathrm{Si}_{3} \mathrm{~N}_{4}$ fiber, incorporated into ceramic matrix, at high temperature can be estimated by using the activation energy of $1273 \mathrm{~kJ} / \mathrm{mol}$.

From Eqs. (1) and (2), $t$ is represented as follows.

$$
t=-\frac{\ln (1-\alpha)}{A} e^{-E / R T}
$$

Fugure 8 shows temperature dependence of $t$ when value of $\alpha$ is assumed 0.01 , which is allowed for practical use such as fiber reinforced composites. ${ }^{12)}$ A value of $t$ at 1300 and $1400^{\circ} \mathrm{C}$ shows about $5 \times 10^{4} \mathrm{~h}$ and $6 \times 10 \mathrm{~h}$, respectively.

\section{Summary}

The crystallization of high purity amorphous polymer-derived $\mathrm{Si}_{3} \mathrm{~N}_{4}$ fiber, which was heat-treated with and without $\mathrm{BN}$ powders, was investigated. In the case without $\mathrm{BN}$ powder, the crystallization proceeds by vapor phase growth mechanism through 
$\mathrm{SiO}$ gas. The activation energy of $602 \mathrm{~kJ} / \mathrm{mol}$ was calculated. In the case with $\mathrm{BN}$ powder, the crystalline growth and crystallization through vapor phase was fairly suppressed. The crystallization proceeds by solid phase growth mechanism. The activation energy of $1273 \mathrm{~kJ} / \mathrm{mol}$ was calculated.

Durability of $\mathrm{Si}_{3} \mathrm{~N}_{4}$ fiber in a ceramic matrix composite was estimated. $\mathrm{Si}_{3} \mathrm{~N}_{4}$ fiber may remain amorphous at $1300^{\circ} \mathrm{C}$ for $5 \times 10^{4} \mathrm{~h}$ and at $1400^{\circ} \mathrm{C}$ for $6 \times 10 \mathrm{~h}$, respectively.

Acknowledgments This work was supported by the Petroleum Energy Center which was subsidized by MITI (Ministry for International Trading and Industry).

\section{References}

1) M. Fukuhara, J. Am. Ceram. Soc., 68, C226-28 (1985).

2) Z. K. Huang, P. Greil and G. Petzow, Ceram. Int., 10, 14-17 (1984).

3) a) O. Funayama, M. Arai, Y. Tashiro, H. Aoki, T. Suzuki,
K. Tamura, H. Kaya, H. Nishii and T. Isoda, Seramikkusu Ronbunshi, 98, 104-07 (1990).

b) T. Isoda, "Controlled Interfases in Composite Materials", Ed. by H. Ishida, Elsevier (1990) pp. 255-65.

4) T. Yamada, T. Kawahito and T. Iwai, J. Mater. Sci. Lett., 2, 275-78 (1983).

5) J. Hojo, H. Maeda and A. Kato, Seramikkusu Ronbunshi, 96, 842-46 (1988).

6) W. R. Schmidt, V. Sukumar, W. J. Hurley, Jr., R. Garcia, R. H. Doremus, L. V. Interrante and G. M. Renlund, J. Am. Ceram. Soc., 73, 2412-18 (1990).

7) T. Yamada, K. Masunaga, T. Kunisawa and Y. Kotoku, Yogyo-Kyokai-Shi, 93, 394-97 (1985).

8) S. Prochazka and C. Greskovich, Am. Ceram. Soc. Bull., 57, 579-86 (1978).

9) S. Futaki, K. Shiraishi, T. Shimizu and T. Yoshida, YogyoKyokai-Shi, 94, 17-21 (1986).

10) D. R. Messier, F. L. Riley and R. J. Brook, J. Mater. Sci., 13, 1199-205 (1978).

11) R. Riedel, J. Eur. Ceram. Soc., 7, 21-25 (1991).

12) K. Sato, T. Suzuki, O. Funayama and T. Isoda, J. Ceram. Soc. Japan, 100, 444-47 (1992). 